\title{
FIELD-SPECIFIC CONVENTIONS IN THE TRANSLATION OF COMMERCIAL LAW DOCUMENTATION FOR COURT PROCEEDINGS
}

\begin{abstract}
The paper presents findings gathered in an exploratory, descriptive, corpus-based analysis of a parallel corpus composed of English corporate documents and their translations into Polish with regard to the frequency-related, binary strategy distribution pattern. In general, the author posits a distinctiveness of interlingual communication in the domain of law, as delineated by the institutional and disciplinary framework. The material extracted from the corpus and studied for its generic features (author, forthcoming-a) points to the hermetic character of corporate written communication in English. The thesis to be verified is whether there are any tendencies in the distribution of the translation strategies in the corpus texts. The research question was operationalised via coding the corpus extracts according to the binary strategy division scheme. Further, the data have been discussed in reference to the sociocultural background of the communicative situation covered under the analysis in order to account for the translators' motivation.

Keywords: interlingual communication, legal translation, commercial law, court setting, frequency distribution, translation strategy, pragmatic motivation, cultural/conceptual contiguity.
\end{abstract}

\section{Introduction}

The quality of translations is often discussed in terms of the application of various technical conventions applied by translators - most commonly - varying between methods, techniques, procedures, and strategies (i.a. Burkhanov, 2003; Newmark, 1981; Nida, 2001). These notions have earned a number of definitions and the distinction between some of these concepts is not always completely transparent (Sun, 2012: 5408; author, 2014b: 44). The paper focuses on investigating the operation of translation strategy referring to the binary distinction, which - in most general terms - specifies the cultural orientation adopted by the translator who has the 
choice of making the text conform to the source language culture (foreignization) or calibrating the text to the cultural background of the target culture (domestication). The binary distinction with the said nomenclature and in the modern sense is first discussed in Venutti's "The Translator's Invisibility - The History of Translation" published in 1995 (Sun, 2012: 5409), although it is said to be grounded in Schleiermacher's distinction into alienation vs. naturalisation (Venutti, 2001: 242) and to be related to a number of other dichotomic approaches to the issue of translation strategy, such as, for example, primäre vs. sekundäre Übersetzung, semantic vs. communicative translation, dokumentarische vs. instrumentelle Übersetzung, direct vs. indirect translation, Textübersetzung vs. Umfeldübersetzung (Burkhanov, 2003: 16; Snell-Hornby, 2006: 145; Venutti 2010: 65-79; author 2014b: 26). ${ }^{1}$

The issue of translation strategy is an interesting one especially in the case of translating culture-bound terms, as addressed by this study, since here the translator faces the challenge of translating terms for which the target language equivalents are not comparable in terms of their semantic range or are non-existent. Such is the case of the proper names investigated in this study focusing on the category of professional and institutional names (e.g. Belczyk, 2009: 247), and document titles (e.g. Belczyk, 2009: 253).

The rationale behind this research into the pragmatic aspects of translation strategies in the field of commercial law rests on the assumption that generally professional communication in the interlingual perspective is to overcome the differences in the language systems (Galdia, 2017: 272), but also it is to be approached on a context-sensitive basis (Jopek-Bosiacka, 2010: 187-188; Nida, 2001: 29-41), which potentially affects the translation mechanics and results in discursive distinctions of the target text. Context affects the translator's decisions because it specifies the disciplinary environment (Bhatia 2017: 4) and thus the terminological repertoire, communicative function (Grabowski, 2015: 23-33; Šarčević, 1997: 18), and generic structure of the communicative situation (Biel 2018: 151; Bhatia, 2008: 166178; Goźdź-Roszkowski, 2016: 51-67). The preliminary assumption here is that conventions in translation practice vary in the inter- and intradisciplinary perspectives. The findings are held to be even more specific if we take account of the culture-bound terminology, as is the case in this study. Engberg (2016: 28) claims that in the domain of law "Concepts differ according to where and when they are situated: They change over time and even closely related concepts will, as a rule, be at least partially different in different national legal systems". It is advocated that cultural knowledge is to be taken into account in transcoding concepts into the target language (e.g. Asad, 2010: 5-27; Baaij, 2014; Matulewska, 2014a: 101-102). 
Such complexity of legal translation calls for the adoption of an individual approach to translating varied texts or even parts of texts, where the employment of the most effective translation strategy is to be preceded by careful consideration of the abovementioned factors. Studies have shown that the distribution of translation strategies in the domain of law escapes any consistent schemes and the reasons can be traced back to the heterogenic character of legal texts and context-dependent communicative functions (author, 2014b; forthcoming-b), which encouraged the author to carry out more detailed analysis in this field.

The hypothesis to be verified in the foregoing is that there exist some tendencies as regards the distribution of the translation strategies employed in the translation of commercial law documents found on court files in the registration proceedings. The aim of the author is to identify the distribution patterns in the domain of translating document titles, professional titles, and institutional names, and to identify possible sociolinguistic motivation and factors triggering the operation of specific strategies referred to as operating schemes.

\section{Methodology}

The data discussed in this paper have been extracted from a customdesigned, parallel corpus of commercial law documents, as found in the specific court setting on files for the calendar year 2017 (National Court Register in Rzeszów, Poland). ${ }^{2}$ The corpus is parallel and it comprises English language documents as source texts and their translations into Polish, hereinafter referred to as texts in translation or target language documents. ${ }^{3}$ It comprises 201 samples, that is, pairs of documents of varied length, origin, and genre type which are exhaustively representative for the institutionally and substantively delineated context covered by the analysis. The number of cases studied for individual values varies due to the cases of lack of data in the court file system, which involves cases of source or target documents missing on the court files, either whole or individual pages, or lack of specific data on a document. In order to pursue the main trends as regards identification of the translation strategies employed in the said context, the author analysed the texts qualitatively and quantitatively with reference to three aspects: document titles, professional titles, and institutional names. The eligible units displaying the three discourse functions were extracted from the corpus and submitted to categorisation into conceptual categories presented in capital letters which have been distinguished individually for the 
three domains. ${ }^{4}$ Further, the linguistic material was coded for the translation strategies within the framework of the binary distinction of foreignization and domestication. The coding for strategy type was conducted against the criterion of functional congruency of the target terminological units with the terminological scheme adopted in the discipline-specific context in the Polish legal system in focus here. Specifically, domestication is assumed when the relevant units are confirmed to make up part of the written professional discourse in the said environment, that is they are used in any type of legal texts: descriptive, prescriptive, or hybrid legal texts. The compatibility of the individual terminological units is ascertained when all the components of the units in question fit into the relevant target language formula, both in terms of their semantics and syntactic structure. The system of coding is determined by the type of variable that we are dealing with here. The variable of translation strategy may be said to belong to the category of qualitative, immeasurable variables which conventionally allow for the adoption of an individual perspective in the statistical description (Nowak, 2006: 124190). ${ }^{5}$ The dichotomic strategy framework in point here does not provide us with unequivocal distinction criteria (Kwieciński, 2001: 120) ${ }^{6}$ and thus the author adopted an individual qualification system based on the criterion of whether the individual units are affiliated to Polish nomenclature in the field of commercial law (domestication) or not (foreignization). The primary qualification is subject to this decision, which is made on an experientialist basis. In order to ensure objectivity, the results of the coding were verified and the author ran the "to be or not to be" test, where 20 randomly selected terminological items previously qualified as domestication were tested for the affiliation parameter.

Apart from presenting the frequency data regarding the distribution of the two strategies, with an attempt to throw some light on the sociocultural background the author conducted cross-table analyses involving data related to the country where the texts come from, the sex of the translator possibly related to the concept of gender identity, and type of translation (certified translation or non-certified translation).

For the purpose of statistical processing, with the aim of presenting tendencies in the distribution of specific values, the distinctions of the research apparatus are transposed into concepts fitting into the scheme of statistical description. The document titles, professional titles, and institutional names, translator's sex, source culture, and type of translation are assigned the status of variables, the categories segmenting the conceptual system emerging from the corpus data function as variable indicators, and the genre markers operating as terminological units materialising the three 
discourse functions are assigned the role of values. The quantitative analysis was performed with the use of the Statistical Package for Social Sciences programme.

In order to draw readers' attention to the main trends regarding how the discursive functions are displayed in the context of interlingual communication, the discussion is organised against a selective data framework. Firstly, when commenting on the data included in the relevant figures the author focusses on values scoring $50 \%$ or more of the total volume of answers for each category, hereinafter referred to as dominant values. Secondly, the author presents the findings emerging from the statistical analysis of correlations (Tables found in the Appendix). Finally, the discussion of the data related to each discursive function ends with the presentation of material illustrative of specific patterns as regards the operating schemes for both strategies, and - when possible - the source of motivation along which the process of translation runs.

\section{Results}

The data extracted from the corpus related to document titles constitute 175 samples and the relevant distribution scheme is presented in Figure 1.

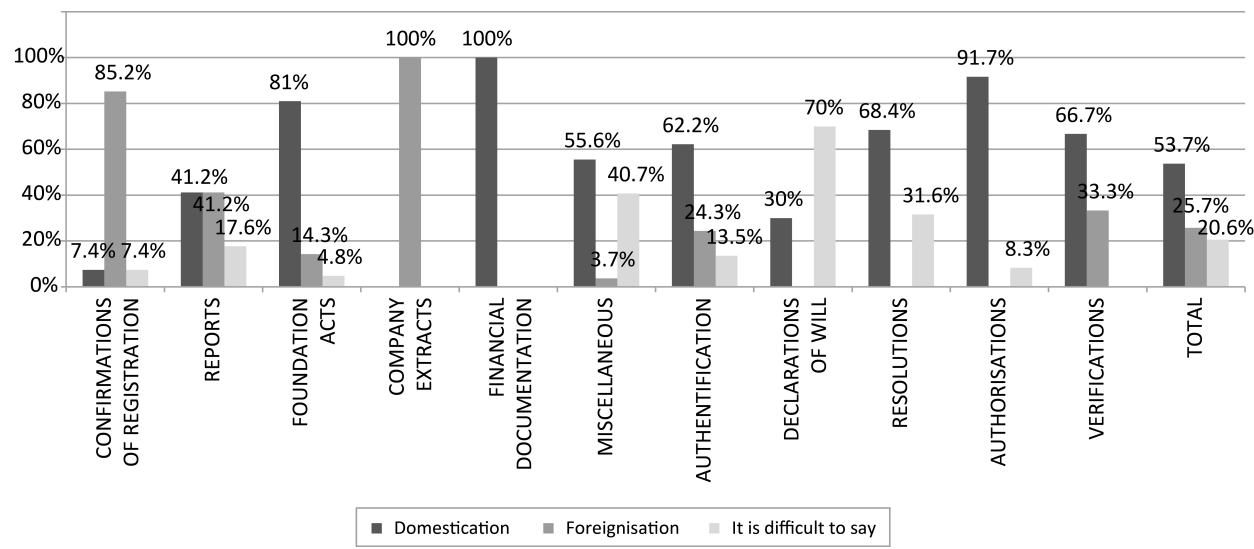

Figure 1. Distribution of the translation strategies in relation to the categories of document titles (prepared by the author)

As evidenced in Figure 1, domestication scores a majority of share in the strategy distribution $(53.7 \%)$. The winning conceptual categories here include in order of priority FINANCIAL DOCUMENTATION (100\%), 
AUTHORISATIONS (91.7\%), FOUNDATION ACTS (81\%), RESOLUTIONS (68.4\%), VERIFICATIONS (66.7\%), and AUTHENTIFICATIONS $(62.2 \%)$. Some part of the lexical material extracted from the corpus relating to the discourse function in point was not eligible for any category and is referred to cumulatively as MISCELLANEOUS. Here, the results coded as domestication strategy also prevail with a score of $55.6 \%$.

In an attempt to identify some tendencies as regards the potential background of the said distribution scheme, the data presented in Figure 1 were correlated with selected variables constituting the sociocultural context (Appendix). The variables include the distinction into certified translation and non-certified translations, sex of the translator, and source culture. The cross-table analysis involving the variable of document title and translation strategy provide us with data that point to the domination of domestication both in the case of certified (46.9\%) and non-certified translations $(70.0 \%)$, the winning margin being higher in the case of the latter. Further, the preference for specific translation strategy seems to correlate with the sex of the translator. Hence, women tend to favour domestication far more than men. The score is $47.7 \%$ on the part of women compared to $35.1 \%$ for men (Appendix, Table 2). Finally, closer study of the correlation between the use of a specific translation strategy and the country from which a given source document comes allows us to localise the focal points of the discrepancy in the distribution of the values in question. Domestication prevails in every single case evidenced in Table 3 in the Appendix. Notably, the single, yet evidenced, cases of units that are not categorised to either domestication or foreignization belong to China (50\%), Denmark (50\%), France (80\%), and Spain (100\%). The conclusion that can be drawn here is that documents coming from outside of Anglo-Saxon culture are rarer in the legal trade conducted in English, which makes them more obscure and likely to be handled untypically by translators of the English language.

The textual analysis of the individual document titles for both strategies allows us to observe some tendencies as regards the consistency of practice. Insofar as in the case of foreignization the translator's decisions seem to present a somewhat dispersed picture with hardly any clear tendencies as regards consistency in the target language recurring formula, the cases annotated as domestication strategy show as conscious, target-oriented actions, directed at fitting into a specific nomenclatural model.

A closer look at the relevant language material shows that the determining factors motivating the operating scheme involve normative conditionings and conceptual contiguity between the source and target cultures on the 
systemic level as regards the individual legal instruments, which facilitates cross-linguistic transmission.

The cases of memorandum «of association» and articles of association, as culturally-conditioned terminological functional variants of the same legal instruments ${ }^{7}$, are illustrative of the first type of motivation, where the driving force for providing domesticated target language counterparts rests in the normative acts setting for the provisions related directly to the documents in translation. Art. 89 of the Act on Freedom of Economic Activity sets forth the requirements of the legislature as regards what documents are to be submitted to the National Court Register to initiate court proceedings in relation to the registration of a branch of a foreign company in Poland. It is normatively prescribed that these are "akt założycielski", "umowa" or "statut" on an "either/or" basis. They are treated by the Polish legislature as having common reference range, which - in the categorisaiton model proposed by the author - is reflected by their affiliation to the conceptual sphere of FOUNDATION ACTS. The enumerative character of the legal provision referred to is due to the conceptual distinctiveness of specific legal institutions related to distinct legal forms in various legal cultures. Individual legal forms of companies, that is a $s p . z$ o.o. "limited liability company" or s.a. "joint stock company" are founded and operated on the basis of distinct types of foundation acts, reflected by distinct terminology. Translators seem to obey the legislature's prescription because a search of the corpus material shows significant consistency in transcoding the terms Memorandum and Articles of Association as "statut «spółki»" , "umowa «spółki»", "akt założycielski «spółki»". Consistency in adopting the domestication strategy here is assumed in this case in spite of the factor of a controlled, yet alternative, choice (2 English terms are translated alternatively with 3 Polish equivalents). The domestication strategy may be implemented in view of significant conceptual contiguity of the source and target terms and the terminological variantivity on the side of the source and target cultures resulting from minor distinctions in the referential range caused by cultural conditionings. The content and form of a founding act of a company in the generic sense of the term is conditioned mainly by the legal form of the company; legal forms of business entities make up a closed, yet culture-specific, list and as such are not comparable on the grounds of substantive law. Legal practice (author, forthcomingb) shows that, in processing documents in translation, functionally statut, akt założycielski, and umowa are held as equivalent and thus the cross-like paradigm in matching the source and target language terms is treated as a case of domestication. 
The second group of document title terms that proves to be consistently translated may be ascribed a common motivation resulting from the conceptual contiguity between the source and target legal cultures in this respect. This operating scheme may be said to be fostered by the cognitive salience of the relevant terms irrespective of the legal discipline, both in English and Polish and - consequently - related high frequency of usage, which causes the appropriation of these terms in the field of corporate, interlingual communication to be found as a marked tendency. The cases in point are annual return "sprawozdanie roczne", balance sheet "bilans", statement "oświadczenie", apostille "apostille", "apostilla", power of attorney "pełnomocnictwo", resolution "uchwała(-y) «zarządu spółki»", minutes "protokół «z posiedzenia zarządu spółki»", lease agreement "umowa najmu" and specimen signature "wzór podpisu".

The analysis of the corpus data in relation to professional titles included therein was conducted on 177 samples. The frequency distribution of the strategies as employed in translating professional titles is illustrated in Figure 2.

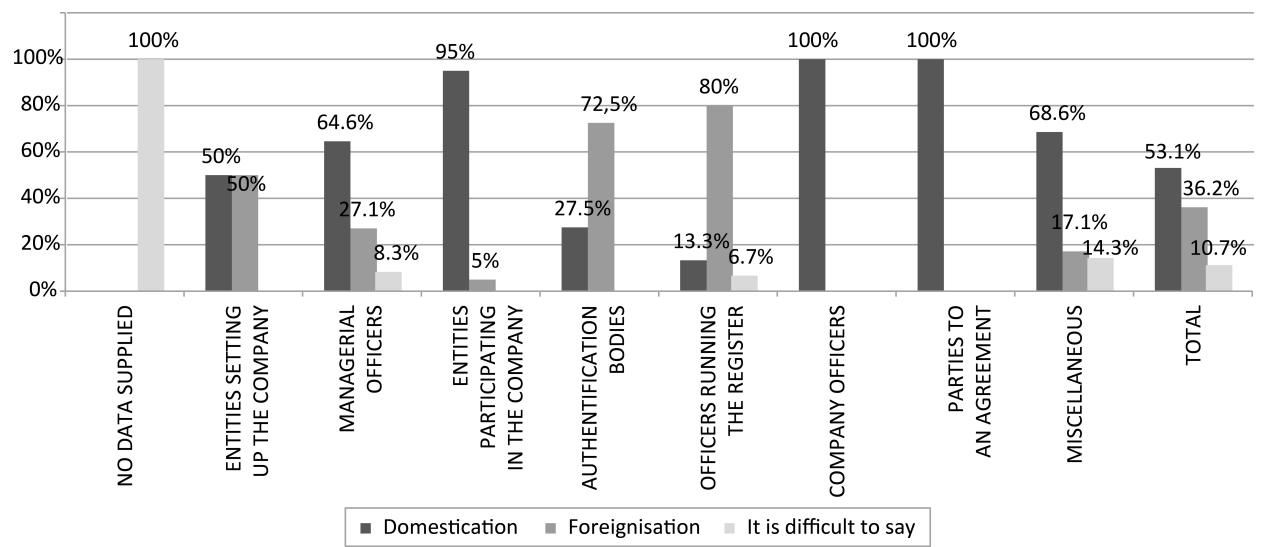

Figure 2. Distribution of the translation strategies in relation to the categories of professional titles (prepared by the author)

The lexical material in point here is spread over eight conceptual categories. The average final result speaks in favour of domestication, coming out with a score of $53.1 \%$ over $36.2 \%$ for foreignization. Compared to document titles, the number of cases that are difficult to classify for either of the strategies is insignificant (10.7\%), as evidenced visually by the blocks labelled "It is difficult to say".

Frequency leaders here include COMPANY OFFICERS and PARTIES TO AN AGREEMENT scoring ex equo 100\% share for the domestication 
in the bipartite strategy distinction. Second place is occupied by ENTITIES PARTICIPATING IN THE COMPANY with the result of 95\%. Next come the categories MISCELLANEOUS, MANAGERIAL OFFICERS and ENTITIES SETTING UP THE COMPANY with scores of $68.6 \%, 64.6 \%$ and $50.0 \%$ respectively. The only dissenters here in terms of the final result are AUTHENTIFICATION BODIES and OFFICERS RUNNING THE REGISTER, where foreignization takes the lead, accounting for $72.5 \%$ and $80 \%$ respectively. The consistency in employing foreignization in the last two cases may result from the culturally idiosyncratic character of the linguistic material conceptually related to these categories, which makes it difficult to fit them into the Polish conceptual and consequently nomenclatural framework.

Considering the variable of the translation strategy employed in translating professional titles in the context of the type of translation (Appendix, Table 1), translator's sex (Appendix, Table 2), and source culture (Appendix, Table 3) shall allow us to establish - if any - the correlation with sociocultural conditionings.

Investigating the binary distinction of translation strategies in the context of document titles separately for certified and non-certified translations brings in data that point to a similar distribution pattern as in the case of document titles. Hence, domestication is found to dominate for both types of translations, with scores of $48.5 \%$ and $80.0 \%$ in favour of domestication respectively.

If we correlate the variable of sex with the distribution of translation strategies applied to translating professional titles, we see a clear tendency, as in the case of document titles. Women are evidenced to favour domestication ( $52.2 \%$ against $40.7 \%$ in favour of domestication). For men the pattern is the reverse (65.0\% against $35.0 \%$ in favour of foreignisation).

As regards the correlation between the country of origin of the source document and the preference for the translation strategy, the picture that emerges from the tabularised data shows as less unequivocal (Appendix, Table 3). The dominance of domestication is ascertained, as in the previous case, but USA and Denmark are excluded here as contravening the overall tendency. The frequency data in point here may testify to a consistent tendency as regards the obscurity of the terms denoting professional titles, which makes it impossible to transcode them into Polish in a functionally loyal way (Šarčević 1997: 13).

The qualitative analysis of the individual parallel items related to the discursive function of specifying professional titles allows us to identify some tendencies as regards the operating schemes involved in the translation pro- 
cess. Notably, cases of domestication, in general, prove to be construed according to a scheme wherein translators are motivated by a disciplinespecific, terminological regime, sanctioned by the wording of the Polish normative legal acts, and operating according to the scheme, accountable by the identification of the conceptual contiguity between the source and target terms. Hence, to illustrate, subscriber is translated as "subskrybent" after the wording of Art. $435 \S 2$ point 1 of the Code of Commercial Companies and incorporator is translated as "założyciel «spółki»" after the wording of Art. 129 of the Code of Commercial Companies. This language material described here in the context of the tendency illustrative for the working mechanism of the domestication strategy, as observed in the corpus analysis, is also informative about the consistent use of foreignized equivalents in translation. The data show that the domesticated Polish equivalents function side by side with the foreignized alternatives. "Inkorporator" paired with incorporator is a case in point, which may be held illustrative of graphically assimilated borrowing $(\mathrm{c}>\mathrm{k})$ from English. Although understandable by virtue of its etymological relatedness with the term as a noun denoting an agent, it is non-existent, in both general and legal language. Cases like this are not infrequent.

The corpus search for trends observed at the level of individual expressions provides us with yet another interesting case, which shows that the source of motivation for the translator resorting to domestication may lie outside the prescriptive legal texts. We may assume here that the operating scheme follows the pattern imposed by the discourse community composed by the agents involved in the communication in the field of commercial law trade. Shareholder, when used in the context of capital companies is found to be consistently translated as "udziałowiec" and it is held as a legitimate, domesticated equivalent in the classification scheme adopted for the purpose of this research, although the relevant prescriptive texts evidence only two functional equivalents, and these are "wspólnik" and "akcjonariusz". "Udziałowiec" is held as a domesticated language variant on the grounds of being used somewhat informally, yet consistently in descriptive texts in the related contextual environment (Gazeta Prawna-a; Gazeta Prawna-b) ${ }^{9}$

Institutional names are the third domain wherein the binary strategy scheme receives its own individual distribution pattern. The statistical data presented in Figure 3 show that the majority of institutional names tend to be translated according to the foreignization strategy (27.2\% over 15.6\%).

Admittedly, in the case of three categories: TAX AUTHORITIES, AUTHENTIFICATION BODIES, and PROVIDERS OF LEGAL SERVICES, 
Field-specific Conventions in the Translation of Commercial Law...

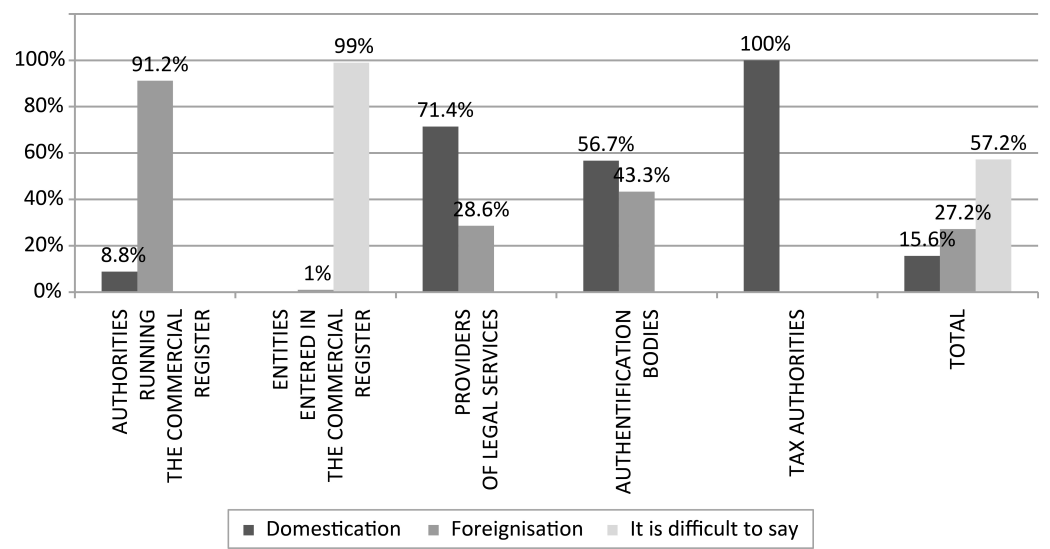

Figure 3. Distribution of the translation strategies in relation to the categories of institutions endorsing the document (prepared by the author)

statistical analysis yields higher scores for domestication, but the results may be incidental here, due to the low numerical values in these categories. In general, as emerges from the graphical representation above, the final winning score of foreignization is to be attributed to the high value for the category AUTHORITIES RUNNING THE COMMERCIAL REGISTER which accounts for $91.2 \%$ of the total volume.

It needs to be stated here that the variable of institutional names is unique, as compared to the other domains covered by the analysis in that a significant number of units here came to be uncategorizable within the bivariate strategy scheme according to the coding procedure adopted. These include institutional names that are business names of the companies fitting into the category ENTITIES ENTERED INTO THE COMMERCIAL REGISTER, which accounts for $99.0 \%$ in favour of the dependent variable labelled as "It is difficult to say". Specificity of the domain covering institutional names should be taken as the status quo.

The correlation of the general frequency data for domestication and foreignization for the variable of institutional names with the variable of translation type shows that the dominance of foreignization is statistically confirmed irrespective of whether we are dealing with certified or non-certified translations (Appendix, Table 1).

Further, the variable of the sex of the translator proves not to condition the choice of the translation strategy in the context of translating institutional names either. The tendency is that both men and women stick to foreignization here (Appendix, Table 2), fitting in with the final distribution pattern, with foreignization as the winner. 
Finally, the variable of source culture of the document correlated with the frequency data in point testify to the existence of two tendencies. Firstly, institutional names in the documents from Sweden and the UK are predominantly found to be foreignized (Appendix, Table 3). The situation is opposite in the case of US documents, where domestication dominates. In turn, in the case of the Netherlands the values for the two strategies acquire equal distribution proportions. In general, it is characteristic for these data that it is impossible to identify any general correlation patterns that would cover a few countries since a number of relevant slots in the Table show a value of $0 \%$, which results from the high percentage of cases that are impossible to bivariately code. A closer look at the relevant corpus extracts informs us that this is the consequence of the coding procedure adopted for company business names making up a majority of the relevant linguistic material.

At the level of individual expressions related to institutional names, we can identify some tendencies as regards the operating schemes. Domestication is found to follow a specific pattern, motivated by the conceptual contiguity between the source and target cultures. The findings are that the Polish equivalents fit in with the systemic and culture-specific institutional framework of the target culture. In general, the repertoire of the relevant corpus extracts is restricted here, as compared to the domain of document titles and professional titles. The discursive function of specifying the institutional names is created by the narrow choice of terminological formula, which is conditioned normatively in that legal provisions set forth specific regulations endowing a restricted range of entities with the competence to issue the said type of documents required in the registration proceedings that determine the context for the study.

The most representative cases here involve Companies House, and District Court Noord Holland. The first English phrase has earned a number of realisations in one of them; "Rejestr Spółek" was coded as domestication on the grounds of making up part of the terminology used in the Code of Commercial Companies (e.g. Art. $158 \S 12$ of the Code of Commercial Companies). This option was identified as a case of domestication although it may be said to be a niche denotation to be used for the institution competent for running the register of commercial law companies. The most frequently occurring term is "Sad Rejestrowy" (e.g. Art. 5 of the Code of Commercial Companies).

As pointed out before, this domestication operating scheme may be said to represent a tendency and it is not employed consistently. To illustrate the background context let us refer to the foreignised alternatives for 
the source term Companies House. These include either retaining the original phrase "Companies House" or employing phrases coined against the Polish prototypical syntagmatic patterns with which the words in use are conventionally associated. The terminological unorthodox formations are contextually unsuited in that they are not in line with Polish official institutional nomenclature in the domain of law under analysis. Cases in point are "Izba Spółek", "Urząd Rejestrowy". The prototypical syntagmatic patterns that are of relevance here may include Krajowa Izba Gospodarcza, Brit. Engl. "National Chamber of Commerce" and Urzad Patentowy, Brit. Engl. "Intellectual Property Office". The terms Companies House may be said to be literally translated against these patterns instead of transcoded and translated with a functional equivalent (transposition or substitution of a legal concept), as advocated by Šarčević (1997: 12).

Another case of phraseological formation of interest here, where the application of the domestication strategy may be said to operate through identifying conceptual contiguity between the cultures involved in the message transfer, is the case of District Court Noord Holland. Here the controversial phrase component district evidenced in the lexicographic sources inconsistently as "rejonowy" or "okręgowy" is here translated mostly as "rejonowy", which testifies to the conceptual congruence achieved via transcoding the message in that functional equivalent is provided. The relevant legal provisions in Poland set forth that National Court Registers are run by sady rejonowe "district courts" (Art. $3 \S 1$ of the Ordinance of the Minister of Justice of 7th October 2017; Art. 2 of the Act of 20th August 1997).

\section{Conclusions}

The study aimed at presenting a national perspective of interlingual corporate communication placed in a specific institutional context. It complements the research on corporate communication (e.g. Biel, 2009; 2010; Bhatia, 2008; 2017, de Groot, 2014; Grant \& Nyberg, 2014) in that the author identifies specific properties of interlingual communication in the communicative situation, which is distinct not only in terms of legal domain but also with regard to the functional parameter defined by company registration proceedings in Poland. This follows the commonly advocated approach of contextualising professional discourse research (i.a. Biel, 2018; Bhatia, 2008: 166).

The findings gathered in the corpus study evidence some tendencies as regards the use of translation strategies in legal communication in the 
context covered by the analysis. To generalise, the domestication strategy shows as more favoured. It dominates in the domain of document titles and professional titles with a score exceeding $50 \%$ of the total volume. It gives way to foreignization only in the case of translating institutional names, with a losing margin of around $12 \%$.

This tendency can be accounted for only in the general perspective, that is with reference to the domains analysed (translating document titles, professional titles, and institutional names) and conceptual categories identified within the three domains. At the level of individual, recurring units, as extracted from the corpus material, the strategy distribution schemes are shown to be significantly dispersed. We can identify some tendencies operating through clear mechanisms, both in the case of domestication and foreignization, but consistency in translation strategy cannot be claimed to be a phrase-inherent feature. Parallel units are found to be translated in a number of ways, annotated as domestication or foreignization, and thus the translators' motivations seem to be arbitrary here.

Admitting the existence of some frequency-related tendencies, the general picture that emerges here points to the observance of the overriding principle of effectiveness of communication understood as mapping the source language cultural scheme onto the normative framework of the target culture. The texts that are submitted to the National Court Registers in Poland in the context delineated in the study are predominantly construed in a way that makes it possible for legal agents to process and conceptualise the notions embodied in the phrases against the legal background of the target culture, and the domestications seem to serve the purpose here.

From the perspective of the operating schemes identified in the translation process, the tendencies in the distribution of the strategies in the specific conceptual categories embracing lexical realisations of document titles, professional titles, and institutional names can be, to some degree, accounted for on the grounds of (i) the substantive legal framework of the target culture, and specifically normative prescription and/or (ii) linguistic contiguity between the source and target legal cultures.

Finally, the cross-table data allow for minor generalisations as regards the translation strategy and type of translation, the sex of the translator, and the country of origin of the document. In general, the variable of type of translation is not found to be a selection criterion for the employment of a specific translation strategy. The overall frequency distribution pattern that we obtain for foreignisation and domestication for the three domains remains consistent (the proportions are found to vary slightly) irrespec- 
tive of whether we are dealing with certified or non-certified translations. In turn, the variable of sex of the translator is found to consistently determine translators' choices with regard to translation strategy. Men are found to consistently employ foreignisation more often throughout all the language material covered by the analysis. Women are fairly consistent in favouring domestication, with the exception of translating institutional names, where their preferences fit into the general distribution scheme with foreignisation as the winner. Finally, for the correlations involving the variable of source culture the most consistent picture emerges in the case of document titles and professional titles. The data for all the individual countries reflect the general tendency for domestication to be the leader. In the domain of institutional names, the dispersion of values should be noted. Namely, the correlation between the said variables for the USA shows as running counter to the overall result, with foreignisation as the winner $(26.7 \% \mathrm{com}$ pared to $15.7 \%$ ). Additionally, some tendencies can be noted as regards the percentage of cases that are difficult to classify. The number of such cases is significantly higher in the domain of document titles and institutional names.

It needs to be stated that the findings presented in this paper should be considered as only illustrative in view of the limited scope of this study, which is restricted to one registration court out of the total number of 21 divisions in Poland. Extending the corpus by inclusion of texts from other units would enable us to confirm the validity of the findings or point to regional distinctions in view of the generic profile of the source texts and/or the consistency of translation practices.

In order to prepare the ground for future research on the translation of commercial law documentation, let us briefly assess some aspects of the methodology and scope of this study. To start with, the findings gathered in the study point to a lack of definite consistency in the use of translation strategies and significant divergence in the discursive performance of translators. The question remains which linguistic choices and conventions adopted by translators are functionally most efficient. The data provide a solid starting point for investigating the communicative expectations of other actors in the communicative situation of the registration proceedings. Some exploratory research in this respect was conducted in the form of a survey (author, forthcoming-b), yet a community practice study focusing on judges and referendaries representing institutional practice could satisfactorily extend the findings by revealing a significant sociocultural perspective of the issue (Dodsworth, 2014: 262-275; Ostermann, 2015: 177-186). It is worth noting that working out a theoretical frame- 
work for consistent translation practice in this respect would undeniably be of great value for the teaching of translation in general (Prieto Ramos, 2011; Chodkiewicz, 2012) and/or preparing guidelines for sworn translators (Biel, 2011; Kubacki, 2012; Kubacki \& Gościński, 2017; 2015; Zieliński, 2014).

Furthermore, it is stressed in the literature of the subject that the degree of difference between languages is one of the main factors that makes efficient translation difficult (Galdia, 2017: 272). In this perspective setting the findings of this study against data from other languages could create an interesting basis for the establishment of a comparative framework in respect of formal and substantive aspects of interlingual communication in the domain of commercial law.

\section{N O T E S}

${ }^{1}$ Kwieciński (2001: 120) emphasises that these oppositions "[...] exhibit only a partial overlap with foreignisation vs. domestication dichotomy [...]" and they are not to be treated as synonymous.

${ }^{2}$ With the intention of placing the study in the relevant disciplinary context referred to by scholars with various labels, which - in most contexts - are functionally synonymous, the author uses the terms commercial law documents (author, forthcoming-b) and corporate documents (Bhatia 2008: 166-178, Bhatia 2017: 88; de Groot, 2014: 237-255; Grant \& Nyberg, 2014: 220-227) interchangeably. Both terms refer to the texts affiliated to the specific normative context of business activity that - here - is narrowed to the court setting, defined by the scope of competence of the registrar of commercial law companies, that is Rejestr Przedsiębiorców "Register of Entrepreneurs" of Krajowy Rejestr Sadowy "National Court Register".

3 The concept of parallel corpus/texts is adopted here in the sense ascribed to it by, among others, Lewandowska-Tomaszczyk, 2005: 51; Matulewska, 2014b: 170; McEnery \& Hardie, 2012: 18-20 and Olohan, 2004: 24-34.

4 This categorization makes up part of the methodological framework used in the study of the generic distinctions in the field of company law communication (author, forthcoming-a).

5 Translation strategy is considered here to be a qualitative variable, which does not allow for the identification of clear borders and representation in the form of ascending or descending order (Nowak, 2006: 124-190). These variables are conventionally considered to be unquantifiable. They can be assigned numbers for the purpose of coding, as is the case in the study, but these numbers are not natural for them and they cannot be considered to express their real features.

6 Scholars often discuss the relevant dichotomic scheme in the context of the fuzzy boundaries between the strategy types. Kwieciński (2001: 120), for example, talks about "degrees of domesticity" and "spectra of exoticism" which imply that these are spaces that are not always clearly delineated.

7 For more on the sociological variantivity of legal communication see (author, $2014 \mathrm{a} ; 2016 \mathrm{~b}$ ) and with regard to the lexicographic and functional distinctiveness of the two terms see author (forthcoming-a). 
8 The examples considered in the foregoing involve the basic, generic formula. The complements occasionally enriching the said phrases (e.g. Resolution «of the Board») are in most cases not considered in the process of categorisation in order to better capture the basic level of consistency. Source terms and quotations are provided in italics and the translations are put in double quotation marks.

9 For more see author (2016a: 284-285).

\section{R E F E R E N C E S}

Asad, T. 2010. The concept of cultural translation in British social anthropology. In M. Baker (Ed.) Critical Readings in Translation Studies (pp. 5-27). New York: Routledge Taylor and Francis Group.

Baaij, C. J.W. 2014. Translation and the 'contamination' of comparative legal research. In S. Glanert (Ed.) Comparative Law - Engaging Translation (pp. 104-121). London and New York: Routledge Taylor and Francis Group.

Belczyk, A. 2009. Poradnik tłumacza. Kraków: Wydawnictwo Idea.

Bhatia, V. K. 2008. Towards critical genre analysis. In V. K. Bhatia, J. Flowerbed, R. H. Jones (Eds.) Advances in Discourse Studies (pp. 166-178). London and New York: Routledge Taylor and Francis Group.

Bhatia, V. K. 2017. Critical Genre Analysis. Investigating Interdiscursive Performance in Professional Practice. London and New York: Routledge Taylor and Francis Group.

Biel, Ł. 2009. Terminologia polskiego, angielskiego i amerykańskiego prawa spółek: organy spółki. In Lingua Legis 17, 46-57.

Biel, Ł. 2010. Terminologia i frazeologia reprezentacji spółki (pełnomocnik, prokurent przedstawiciel) oraz ich angielskie ekwiwalenty. In Lingua Legis 18, $26-42$.

Biel, Ł. 2011. Jakość przekładu prawnego i prawniczego w świetle normy Europejskiej PN-EN 15038 oraz hipotezy uniwersaliów translatorycznych. In Rocznik Przekładoznawczy. Studia nad Teoria i Dydaktyka Przekładu, 6, $13-28$.

Biel, Ł. 2018. Genre analysis and translation. In K. Malmkjaer (Ed.) The Routledge Handbook of Translation Studies in Linguistics (pp. 151-164). Routledge: New York.

Burkhanov, I. 2003. Translation: Theoretical Prerequisites. Rzeszów: Wydawnictwo Uniwersytetu Rzeszowskiego.

Chodkiewicz, M. 2012. The EMT framework of reference for competencies applied to translation: perceptions by professional and student translators. In The Journal of Specialised Translation, 17 January, 37-54. 
de Groot, E. 2014. Corporate communication and the role of annual reporting. In V. Bhatia, S. Bremner (Ed.) The Routledge Handbook of Language and Professional Communication (pp. 237-255). New York: Routledge Taylor and Francis.

Dodsworth, R. 2014. Speech communities, social networks, and communities of practice. In J. Holmes, K. Hazen (Eds.) Research Methods in Sociolinguistics. A Practical Guide (pp. 262-275). Wiley Blackwell.

Engberg, J. 2016. Conceptualising corporate criminal liability: legal linguistics and the combination of descriptive lenses. In G. Tessuto, V. K. Bhatia, G. Garzone, R. Salvi, Ch. Williams (Eds.) Constructing Legal Discourses and Social Practises: Issues and Perspectives (pp. 28-56). Newcastle upon Tyne: Cambridge Scholars.

Galdia, M. 2017. Lectures on Legal Linguistics. Frankfurt am Main: Peter Lang.

Goźdź-Roszkowski, S. 2016. The role of generic competence and professional expertise in legal translation. The case of English and Polish probate documents. In Studies in Logic, Grammar and Rhetoric, vol. 45(58), 51-67.

Grabowski, Ł. 2015. Keywords and lexical bundles within English pharmaceutical discourse: A corpus-driven description. In English for Specific Purposes, 38, 23-33.

Grant D. \& Nyberg D. 2014. Corporate Communication. In V. Bhatia, S. Bremner (Eds.) The Routledge Handbook of Language and Professional Communication (pp. 220-227). New York: Routledge Taylor and Francis.

Jopek-Bosiacka, A. 2010. Legal Communication: A Cross-Cultural Perspective. Warsaw. Warsaw University Press.

Kubacki, A. D. 2012. Tłumaczenia Poświadczone. Status, Kształcenie, Warsztat Odpowiedzialność Tłumacza Przysiegłego. Warszawa: Wolters Kluwer.

Kubacki, A. \& Gościński, J. 2015. What are sworn translators punished for? 10 years of operation of the Commission for Professional Accountability of Sworn Translators at the Minister of Justice. Comparative Legilinguistics, vol. $23 / 2015,7-17$.

Kubacki, A. \& Gościński, J. 2017. 10 lat działalności Komisji Odpowiedzialności Zawodowej Tłumaczy Przysięłych przy Ministrze Sprawiedliwości. Próba Podsumowania. In Rocznik Przektadoznawczy. Studia nad Teoria i Dydaktywa Przekładu, 6, 201-215. DOI:hhp://dx.doi.org/10.12775/RP.2017.012

Kwieciński, P. (2001). Disturbing Strangeness. Foreignisation and Domestication in Translation Procedures in the Context of Cultural Asymmetry. Inowrocław: Zakład Poligraficzno-Wydawniczy.

Lewandowska-Tomaszczyk, B. 2005. Podstawy Jezykoznawstwa Korpusowego. Łódź: Wydawnictwo Uniwersytetu Łódzkiego.

Matulewska, A. 2014a. Horrory tłumaczeniowe czy tłumacze z piekłą rodem? Czyli kilka słów o efektywności komunikacji interlingwalnej. In Scripta Neophilologica Posnaniensia, Ed. Stanisław Puppel. Vol. XIV, 101-119. 
Matulewska, A. 2014b. In quest of sufficient equivalence, Polish and English insolvency. In Studies in Logic, Grammar and Rhetoric 38 (51), 167-188.

McEnery, T. \& Hardie A. 2012. Corpus Linguistics. Method, Theory and Practice. Cambridge: Cambridge University Press.

Newmark, P. 1981. Approaches to Translation. Oxford: Pergamon.

Nida, E. 2001. Contexts in Translating. Amsterdam/Philadelphia: John Benjamins Publishing Company.

Nowak, S. 2006. Metodologia Badań Społecznych. Warszawa: Wydawnictwo Naukowe PWN.

Olohan, M. 2004. Introducing Corpora in Translation Studies. London and New York: Routledge Taylor and Francis Group.

Ostermann, A. C. 2015. Community of Practice. In K. Tracy (Ed.) The International Encyclopedia of Language and Social Interaction (pp. 177-186). Wiley-Blackwell.

Prieto Ramos, F. 2011. Developing Legal Translation Competence: An Integrative Process-Oriented Approach. In Comparative Legilinguistics - International Journal for Legal Communication, vol. 5, 7-21.

Snell-Hornby, M. 2006. Turns of Translation Studies. Amsterdam: John Benjamins Publishing Company.

Sun, S. 2012. Strategies of Translation. In C. A. Chapelle (ed.) The Encyclopedia of Applied Linguistics vol. IX (pp. 5408-5412). Wiley-Blackwell.

Šarčević, S. 1997. New Approach to Legal Translation. The Hague: Kluwer Law International.

Venutti, L. 1995. The Translator's Invisibility - The History of Translation. New York: Routledge.

Venutti, L. 2001. Strategies of Translation. In M. Baker (Ed.) Routledge Encyclopedia of Translation Studies (pp. 240-244). London and New York: Routledge.

Venutti, L. 2010. Translation as cultural politics: Régimes of domestication in English. In M. Baker (Ed.) Critical Readings in Translation Studies (pp. 65-79). New York: Routledge Taylor and Francis Group.

Więcławska, E. 2014a. Common law Englishes in legal communication - the case of family law. In L. Falkiewicz-Wille, M. Pikor-Niedziałek (Eds.) Specialist Languages in Use and Translation (pp. 59-70). Rzeszów: Wydawnictwo Uniwersytetu Rzeszowskiego.

Więcławska. E. 2014b. Translation strategies in legal texts. In M. Wierzbicka, L. Wille (Eds.) In the Field of Contrastive and Applied Linguistics (pp. 4355). Rzeszów: Wydawnictwo Uniwersytetu Rzeszowskiego.

Więcławska, E. 2016a. Horizontal and vertical distribution patterns of nearlysynonymous terms in the language of law. In Humanities and Social Sciences no. 23 (4/2016), 281-291. 
Więcławska, E. 2016b. Integrating the needs of the local market in teaching legal translation. Humanities and Social Sciences, no. 23, 245-253.

Więcławska, E. (forthcoming-a). Towards the establishment of genre distinctions of company legal registration proceedings. In Komunikacja Specjalistyczna no. 16 .

Więcławska, E. (forthcoming-b).Capitalising on translation market data in the field of commercial law. In Comparative Legilinguistics, International Journal for Legal Communication.

Zieliński, J. 2015. Sprawozdanie Komisji Odpowiedzialności Zawodowej Tłumaczy Przysięgłych w Ministerstwie Sprawiedliwości za rok 2014. Biuletyn TEPIS, $82,39-44$.

\section{Selected source texts}

Act on Freedom of Economic Activity [Ustawa z dnia 2 lipca 2004 r. o Swobodzie Działalności Gospodarczej (Journal of Laws of 2004, no. 174, item 1807 with later amendments)].

Act of 20th August 1997 [Ustawa z dnia 20 sierpnia 1997 r. - Przepisy wprowadzajace ustawe o Krajowym Rejestrze Sadowym (Journal of Laws of 1997, no. 121, item 770 with later amendments)].

Code of Commercial Companies [Ustawa z dnia 15 września 2000 r. Kodeks Spółek Handlowych. (Journal of Laws of 2000, no. 94, item 1037 with later amendments)].

Gazeta Prawna-a [Mniejszościwego udziałowca można wyłączyć ze spółki. In Gazeta Prawna.] Retrieved January 2018 from the website: http://prawo.gazetapraw na.pl/artykuly/700281,mniejszosciowego-udzialowca-mozna-wylaczyc-ze-spo lki.html

Gazeta Prawna-b [Axel Springer zostaje mniejszościowym udziałowcem Infor Biznes. In Gazeta Prawna.] Retrieved January 2018 from the website: http:// biznes.gazetaprawna.pl/artykuly/322143,axel-springer-zostaje-mniejszo sciowym-udzialowcem-infor-biznes.html

Ordinance of the Minister of Justice of 7th October 2014 [Rozporzacdzenie Ministra Sprawiedliwości z dnia 7 października 2014 r. w sprawie przekazania niektórym sądom okręgowym i sądom rejonowym rozpoznawania spraw gospodarczych z obszarów właściwości innych sądów okręgowych i sądów rejonowych (Journal of Laws of 2014, item 1397)]. 
Field-specific Conventions in the Translation of Commercial Law...

Attachment

Table 1

Cross tabulation between strategy and type of translation

\begin{tabular}{|c|c|c|c|c|c|}
\hline \multirow{10}{*}{  } & & & \multicolumn{2}{|c|}{ TYPE OF TRANSLATION } & \multirow[b]{2}{*}{ TOTAL } \\
\hline & & & $\begin{array}{c}\text { Non-certified } \\
\text { translations }\end{array}$ & $\begin{array}{c}\text { Certified } \\
\text { translations }\end{array}$ & \\
\hline & \multirow{2}{*}{ Domestication } & $\mathrm{N}$ & 45 & 61 & 96 \\
\hline & & $\%$ & $70.0 \%$ & $46.9 \%$ & $53.3 \%$ \\
\hline & \multirow{2}{*}{ Foreignisation } & $\mathrm{N}$ & 0 & 46 & 46 \\
\hline & & $\%$ & $.0 \%$ & $35.4 \%$ & $25.6 \%$ \\
\hline & \multirow{2}{*}{ It is difficult to say } & $\mathrm{N}$ & 15 & 23 & 38 \\
\hline & & $\%$ & $30.0 \%$ & $17.7 \%$ & $21.1 \%$ \\
\hline & \multirow{2}{*}{ Total } & $\mathrm{N}$ & 50 & 130 & 180 \\
\hline & & $\%$ & $100.0 \%$ & $100.0 \%$ & $100.0 \%$ \\
\hline \multirow{8}{*}{ 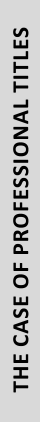 } & \multirow{2}{*}{ Domestication } & $\mathrm{N}$ & 40 & 64 & 104 \\
\hline & & $\%$ & $80.0 \%$ & $48.5 \%$ & $57.1 \%$ \\
\hline & \multirow{2}{*}{ Foreignisation } & $\mathrm{N}$ & 6 & 60 & 66 \\
\hline & & $\%$ & $12.0 \%$ & $45.5 \%$ & $36.3 \%$ \\
\hline & \multirow{2}{*}{ It is difficult to say } & $\mathrm{N}$ & 4 & 8 & 12 \\
\hline & & $\%$ & $8.0 \%$ & $6.1 \%$ & $6.6 \%$ \\
\hline & \multirow{2}{*}{ Total } & $\mathrm{N}$ & 50 & 132 & 182 \\
\hline & & $\%$ & $100.0 \%$ & $100.0 \%$ & $100.0 \%$ \\
\hline \multirow{8}{*}{ 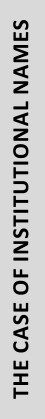 } & \multirow{2}{*}{ Domestication } & $\mathrm{N}$ & 1 & 28 & 29 \\
\hline & & $\%$ & $2.0 \%$ & $21.4 \%$ & $16.0 \%$ \\
\hline & \multirow{2}{*}{ Foreignisation } & $\mathrm{N}$ & 2 & 48 & 50 \\
\hline & & $\%$ & $4.0 \%$ & $36.6 \%$ & $27.6 \%$ \\
\hline & \multirow{2}{*}{ It is difficult to say } & $\mathrm{N}$ & 47 & 55 & 102 \\
\hline & & $\%$ & $94.0 \%$ & $42.0 \%$ & $56.4 \%$ \\
\hline & \multirow{2}{*}{ Total } & $\mathrm{N}$ & 50 & 131 & 181 \\
\hline & & $\%$ & $100.0 \%$ & $100.0 \%$ & $100.0 \%$ \\
\hline
\end{tabular}


Edyta Więcławska

Table 2

Cross tabulation between strategy and gender of the translator

\begin{tabular}{|c|c|c|c|c|c|}
\hline \multirow{10}{*}{ 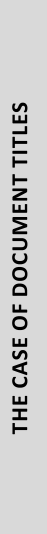 } & & & \multicolumn{2}{|c|}{ SEX } & \multirow{2}{*}{ TOTAL } \\
\hline & & & $M$ & $\mathrm{~F}$ & \\
\hline & \multirow{2}{*}{ Domestication } & $\mathrm{N}$ & 5 & 53 & 58 \\
\hline & & $\%$ & $25.0 \%$ & $47.7 \%$ & $44.3 \%$ \\
\hline & \multirow{2}{*}{ Foreignisation } & $\mathrm{N}$ & 6 & 39 & 45 \\
\hline & & $\%$ & $30.0 \%$ & $35.1 \%$ & $34.4 \%$ \\
\hline & \multirow{2}{*}{ It is difficult to say } & $\mathrm{N}$ & 9 & 19 & 28 \\
\hline & & $\%$ & $45.0 \%$ & $17.1 \%$ & $21.4 \%$ \\
\hline & \multirow{2}{*}{ Total } & $\mathrm{N}$ & 20 & 111 & 131 \\
\hline & & $\%$ & $100.0 \%$ & $100.0 \%$ & $100.0 \%$ \\
\hline \multirow{8}{*}{ 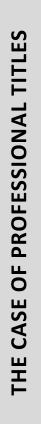 } & \multirow{2}{*}{ Domestication } & $\mathrm{N}$ & 7 & 59 & 66 \\
\hline & & $\%$ & $35.0 \%$ & $52.2 \%$ & $49.6 \%$ \\
\hline & \multirow{2}{*}{ Foreignisation } & $\mathrm{N}$ & 13 & 46 & 59 \\
\hline & & $\%$ & $65.0 \%$ & $40.7 \%$ & $44.4 \%$ \\
\hline & \multirow{2}{*}{ It is difficult to say } & $\mathrm{N}$ & 0 & 8 & 8 \\
\hline & & $\%$ & $.0 \%$ & $7.1 \%$ & $6.0 \%$ \\
\hline & \multirow{2}{*}{ Total } & $\mathrm{N}$ & 20 & 113 & 133 \\
\hline & & $\%$ & $100.0 \%$ & $100.0 \%$ & $100.0 \%$ \\
\hline \multirow{8}{*}{ 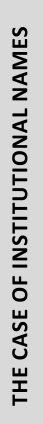 } & \multirow{2}{*}{ Domestication } & $\mathrm{N}$ & 0 & 29 & 29 \\
\hline & & $\%$ & $.0 \%$ & $25.9 \%$ & $22.0 \%$ \\
\hline & \multirow{2}{*}{ Foreignisation } & $\mathrm{N}$ & 13 & 36 & 49 \\
\hline & & $\%$ & $65.0 \%$ & $32.1 \%$ & $37.1 \%$ \\
\hline & \multirow{2}{*}{ It is difficult to say } & $\mathrm{N}$ & 7 & 47 & 54 \\
\hline & & $\%$ & $35.0 \%$ & $42.0 \%$ & $40.9 \%$ \\
\hline & \multirow{2}{*}{ Total } & $\mathrm{N}$ & 20 & 112 & 132 \\
\hline & & $\%$ & $100.0 \%$ & $100.0 \%$ & $100.0 \%$ \\
\hline
\end{tabular}


Field-specific Conventions in the Translation of Commercial Law...

Table 3

Cross tabulation between strategy and source culture

\begin{tabular}{|c|c|c|c|c|c|c|c|c|c|c|c|c|}
\hline \multirow{10}{*}{ 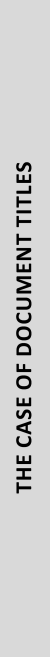 } & & & & \multicolumn{8}{|c|}{ SOURCE CULTURE } & \multirow{2}{*}{ TOTAL } \\
\hline & & & & China & Denmark & France & Nerherlands & Spain & Sweden & UK & USA & \\
\hline & \multirow{6}{*}{ 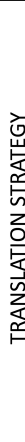 } & \multirow{2}{*}{  } & $\mathrm{N}$ & & 3 & 1 & 4 & 0 & & 57 & & \\
\hline & & & $\%$ & $50.0 \%$ & $50.0 \%$ & $20.0 \%$ & $100.0 \%$ & $.0 \%$ & $53.8 \%$ & $61.3 \%$ & $39.6 \%$ & $53.5 \%$ \\
\hline & & 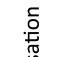 & $\mathrm{N}$ & 0 & 0 & 0 & 0 & 0 & 6 & 30 & 8 & 44 \\
\hline & & $\begin{array}{l}\overline{.00} \\
\overline{0} \\
\overline{0}\end{array}$ & $\%$ & $.0 \%$ & $.0 \%$ & $.0 \%$ & $.0 \%$ & $.0 \%$ & $46.2 \%$ & $32.3 \%$ & $16.7 \%$ & $25.6 \%$ \\
\hline & & $\frac{ \pm}{\vec{J}}$ & $N$ & 1 & 3 & 4 & 0 & 1 & 0 & 6 & 21 & 36 \\
\hline & & $\underline{ \pm}+$ & $\%$ & $50.0 \%$ & $50.0 \%$ & $80.0 \%$ & $.0 \%$ & $100.0 \%$ & $.0 \%$ & $6.5 \%$ & $43.8 \%$ & $20.9 \%$ \\
\hline & \multirow{2}{*}{\multicolumn{2}{|c|}{ TOTAL }} & $\mathrm{N}$ & 2 & 6 & 5 & 4 & 1 & 13 & 93 & 48 & 172 \\
\hline & & & $\%$ & $100.0 \%$ & $100.0 \%$ & $100.0 \%$ & $100.0 \%$ & $100.0 \%$ & $100.0 \%$ & $100.0 \%$ & $100.0 \%$ & $100.0 \%$ \\
\hline \multirow{8}{*}{ 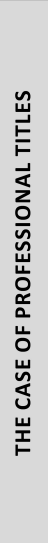 } & \multirow{6}{*}{ 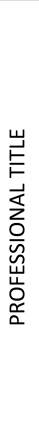 } & \multirow{2}{*}{ 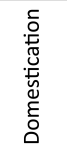 } & $\mathrm{N}$ & 1 & 2 & 5 & 2 & 1 & 10 & 63 & 17 & 101 \\
\hline & & & $\%$ & $50.0 \%$ & $33.3 \%$ & $100.0 \%$ & $40.0 \%$ & $100.0 \%$ & $76.9 \%$ & $67.7 \%$ & $35.4 \%$ & $58.4 \%$ \\
\hline & & \multirow{2}{*}{ 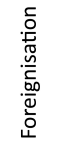 } & $\mathrm{N}$ & 1 & 4 & 0 & 1 & 0 & 3 & 28 & 25 & 62 \\
\hline & & & $\%$ & $50.0 \%$ & $66.7 \%$ & $.0 \%$ & $20.0 \%$ & $.0 \%$ & $23.1 \%$ & $30.1 \%$ & $52.1 \%$ & $35.8 \%$ \\
\hline & & \multirow{2}{*}{ 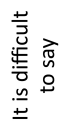 } & $N$ & 0 & 0 & 0 & 2 & 0 & 0 & 2 & 6 & 10 \\
\hline & & & $\%$ & $.0 \%$ & $.0 \%$ & $.0 \%$ & $40.0 \%$ & $.0 \%$ & $.0 \%$ & $2.2 \%$ & $12.5 \%$ & $5.8 \%$ \\
\hline & \multirow{2}{*}{\multicolumn{2}{|c|}{ TOTAL }} & $\mathrm{N}$ & 2 & 6 & 5 & 5 & 1 & 13 & 93 & 48 & 173 \\
\hline & & & $\%$ & $100.0 \%$ & $100.0 \%$ & $100.0 \%$ & $100.0 \%$ & $100.0 \%$ & $100.0 \%$ & $100.0 \%$ & $100.0 \%$ & \\
\hline \multirow{8}{*}{ 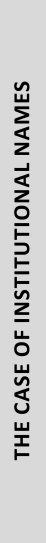 } & \multirow{6}{*}{  } & \multirow{2}{*}{ 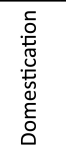 } & $\mathrm{N}$ & 0 & 0 & 0 & 1 & 0 & 2 & 4 & 20 & 27 \\
\hline & & & $\%$ & $.0 \%$ & $.0 \%$ & $.0 \%$ & $20.0 \%$ & $.0 \%$ & $15.4 \%$ & $4.3 \%$ & $42.6 \%$ & $15.7 \%$ \\
\hline & & \multirow{2}{*}{ 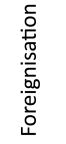 } & $\mathrm{N}$ & 0 & 0 & 0 & 1 & 0 & 6 & 29 & 10 & 46 \\
\hline & & & $\%$ & $.0 \%$ & $.0 \%$ & $.0 \%$ & $20.0 \%$ & $.0 \%$ & $46.2 \%$ & $30.9 \%$ & $21.3 \%$ & $26.7 \%$ \\
\hline & & \multirow{2}{*}{ 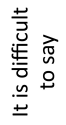 } & $\mathrm{N}$ & 2 & 6 & 4 & 3 & 1 & 5 & 61 & 17 & 99 \\
\hline & & & $\%$ & $100.0 \%$ & $100.0 \%$ & $100.0 \%$ & $60.0 \%$ & $100.0 \%$ & $38.5 \%$ & $64.9 \%$ & $36.2 \%$ & $57.6 \%$ \\
\hline & \multirow{2}{*}{\multicolumn{2}{|c|}{ TOTAL }} & $\mathrm{N}$ & 2 & 6 & 4 & 5 & 1 & 13 & 94 & 47 & 172 \\
\hline & & & $\%$ & $100.0 \%$ & $100.0 \%$ & $100.0 \%$ & $100.0 \%$ & $100.0 \%$ & $100.0 \%$ & $100.0 \%$ & $100.0 \%$ & $100.0 \%$ \\
\hline
\end{tabular}

